Paideusis

\title{
Cultivating Compassion 慈: A Daoist Perspective
}

\section{Tom Culham}

Volume 21, numéro 2, 2014

\section{Working Compassion}

URI : https://id.erudit.org/iderudit/1071564ar

DOI : https://doi.org/10.7202/1071564ar

Aller au sommaire du numéro

Éditeur(s)

Canadian Philosophy of Education Society

ISSN

0838-4517 (imprimé)

1916-0348 (numérique)

Découvrir la revue

\section{Citer cet article}

Culham, T. (2014). Cultivating Compassion 慈: A Daoist Perspective. Paideusis, 21(2), 32-41. https://doi.org/10.7202/1071564ar

\section{Résumé de l'article}

The purpose of this paper is to make a contribution to our working knowledge, practice and pedagogy of compassion through consideration of a Daoist perspective on the matter. I begin with a consideration of Daoist cosmology and a sage's compassion drawn primarily from the Daodejing, This serves as a backdrop to consider Daoist contemplative pedagogy for the cultivation of virtue and compassion. Consistent with Daoist practices which rely on exemplars as a means of inspiring others I justify considering Nelson Mandela an exemplar of compassion. I then discuss how his life lines up with the Daoist conception of compassion. Finally I discuss the practicalities of developing compassion along with other virtues in post-secondary business ethics education classes. These classes work with the following principles: starting small, self- compassion, person to person connections and relationship. Students engage in emotional intelligence activities including: exercises to know their purpose or calling, meditative exercises that help them become aware of their emotions, and structured interpersonal interaction challenging them to develop new social skills. While this work is in its early stages it appears to assist students in developing compassion for others.
Ce document est protégé par la loi sur le droit d'auteur. L'utilisation des services d'Érudit (y compris la reproduction) est assujettie à sa politique d'utilisation que vous pouvez consulter en ligne.

https://apropos.erudit.org/fr/usagers/politique-dutilisation/ 
Paideusis, Volume 21 (2014), No. 2, pp. 32-41

\title{
Cultivating Compassion 慈: A Daoist Perspective
}

\author{
TOM CULHAM \\ University of British Columbia
}

The purpose of this paper is to make a contribution to our working knowledge, practice and pedagogy of compassion through consideration of a Daoist perspective on the matter. I begin with a consideration of Daoist cosmology and a sage's compassion drawn primarily from the Daodejing, This serves as a backdrop to consider Daoist contemplative pedagogy for the cultivation of virtue and compassion. Consistent with Daoist practices which rely on exemplars as a means of inspiring others I justify considering Nelson Mandela an exemplar of compassion. I then discuss how his life lines up with the Daoist conception of compassion. Finally I discuss the practicalities of developing compassion along with other virtues in post-secondary business ethics education classes. These classes work with the following principles: starting small, selfcompassion, person to person connections and relationship. Students engage in emotional intelligecne activities including: exercises to know their purpose or calling, meditative exercises that help them become aware of their emotions, and structured interpersonal interaction challenging them to develop new social skills. While this work is in its early stages it appears to assist students in developing compassion for others.

\section{Introduction}

There has been a resurgence of interest in compassion in the west. For example, Karen Armstrong created the Charter for Compassion in 2008 and tirelessly advocated the adoption of compassion in everyday life with the publication of 12 Steps to a Compassionate Life and other activities. The Charter for Compassion (2013) states:

The principle of compassion lies at the heart of all religious, ethical and spiritual traditions, calling us always to treat all others as we wish to be treated ourselves. Compassion impels us to work tirelessly to alleviate the suffering of our fellow creatures, to dethrone ourselves from the centre of our world and put another there, and to honour the inviolable sanctity of every single human being, treating everybody, without exception, with absolute justice, equity and respect. (para 3)

Armstrong has noted that compassion is a universally recognized human experience that puts into action the fundamental social nature of what it means to be human. Our lives would not be possible without the countless presence of known and unknown others in our lives. Recognizing and acting on this interconnectedness from the heart is part of what it means to have compassion. It is what is needed in our world today with the pressures of population growth, environmental degradation, social disparity, and excessive selfishness.

(C) Copyright 2014. The author, Tom Culham, assigns to Paideusis the right of first publication and educational and non-profit institutions a non-exclusive license to use this document for personal use and in courses of instruction provided that the article is used in full and this copyright statement is reproduced. Any other usage is prohibited without the express permission of the author. 
Given the universality of compassion I believe that Daoist theory and practice can make a contribution to our working knowledge, practice and pedagogy of compassion. Therefore, this paper first explores Daoist compassion in the context of its cosmology and then considers how this informs a practical pedagogy of compassion.

\section{The Daoist Cosmology and Compassion}

The ancient Chinese considered compassion (慈 $c$ ) to be a part of humaneness (仁 ren) (Meyer, 2010). To put this into a cosmological context, the Daoists from ancient times to the present hold that matters fall into the realms of Heaven, Human and Earth. Human beings in between Heaven and Earth, held the middle ground and are recipients of the gifts and subject to the vagaries of Earth and Heaven. "The Quintessential Spirit is what we receive from Heaven; the physical body is what we are given by Earth" (Roth, 2010b p, 241). So compassion as a human way of being or state of mind falls into the realm of human affairs between Heaven and Earth. However, in this view humans are not considered to be separate from Heaven and Earth rather they are intwined in it, play an integral role and contained a microcosm of the universe within them.

The roundness of the head is in the image of Heaven: the squareness of human feet is in the image of the Earth. ... In this way humag beings form a triad with Heaven and Earth, and the mind is the ruler of this. (Roth, 2010b, p. 241)

The Daodejing, translated as the classic of the dao and its Virtue $(d e)$, is considered a classic text of Daoism. It positions compassion primarily within the human relm beneath heaven. Chapter 17 says: "With the highest kind of rulers, those below simply know they exist. With those one step down-they love and praise them" (Henricks, 1989, p. 69). Chapter 19 says: "Eliminate sageliness, throw away knowledge, and the people will benefit a hundredfold, Eliminate Humanity, throw away righteousness, and the people will return to filial piety and compassion (Hendricks, 1989, p. 71). Both of these chapters begin with references to Sages who are one with the dao and contribute to society simply because of their presence and cultivation of virtue. They need take no particular action, apply no book knowledge, nor are they known by the people because they are aligned with the dao and this alignment enables all to benefit (Henricks, 1989). Rulers who are not quite at the level of those in union with the dao are known to the people and loved by the people and the consequence is that filial piety and compassion spontaneously emerge in the populace. These rulers do not have to practice the Humaneness and Rightness advocated by the Confucians as their compassion emerges as a consequence of their cultivation. This interpretation demonstrates that compassion falls within the human realm and according to the Daoists it emerges as a consequence of inner cultivation.

\section{Daoist Compassion and Human Affairs}

It is worth noting that in the Daoist view, compassion isn't quite human because it is of the Heavens. "Such rare cultivated human beings are conjoined with the Way even as they interact in the human realm" (Roth, 2010a, p. 81). Many people find it difficult to embody this quality because it is difficult to overcome judgment of others with apparent moral failings or overcome resentment and anger in the face of enemies or persons who have wronged one. Judgment and revenge or retribution are the usual human responses to such situations.

Daoists hold that everything, living and nonliving, emanates from the dao and as such contains some element of the dao within it. In human terms, all contain the spark of dao but it is muddied or covered over by culture, upbringing and circumstance (Major, Queen, Meyer, \& Roth, 2010). Because the dao is within all humans, there is always a possibility that it can emerge and express itself as virtue in the life of the individual, therefore, all, high and low are worthy of compassion. According to the Daodejing, neither the dao nor the Sage are ultimately humane (Meyer, 2010, p. 885) but paradoxically compassion is not a trivial matter for humans. 
The Daodejing dedicates approximately half of the book to dao (chapters 1 through 37) and half to De (virtue) (chapters 38 through 81) therefore. Within the half of the book on virtue, Chapter 67 addresses compassion along with frugality and humility. It reads:

I constantly have three treasures;

Hold on to them and treasure them.

The first is compassion;

The second is frugality;

And the third is not presuming to be at the forefront in the world.

Now, it's because I'm compassionate that I therefore can be courageous;

And it's because I'm frugal that I therefore can be magnanimous;

And it's because I don't presume to be at the forefront in the world that I therefore can be the head of those with complete talent.

Now, if you abandon this compassion and yet try to be courageous, And if you abandon this frugality and yet tried to be magnanimous, And if you abandon this staying behind in and go to the fore, Then you will die.

If with compassion you attack, then you'll win;

If you defend, then you'll stand firm

When heaven is about to establish him

It's as though he surrounds him with the protective wall of compassion. (Henricks, 1989, p. 38)

In this passage compassion is first among three treasures: compassion, frugality, and humility and it articulates the positive and negative consequences of acting with and without compassion: you will win, you will stand firm, and you will be protected. If you do not practice these treasures the consequence is you will die. This could be interpreted in a number of ways. I believe this is a reference to the Daoist view that Sages through a high level of cultivatation achieve immortality. So the negative consequence of not practicing the three treasures is loss of immortality. The proposal in this section of the Daodejing is that there are defineable negative consequences to the individual who does not practice the three treasures. In the following paragraphs I elaborate on the significance of these treasures through reference to other chapters of the Daodejing.

\section{The Daoist Sage and Compassion}

Chapter 2 of the Daodejing provides a list of opposites two of which include: "When everyone in the world knows the beautiful as beautiful, ugliness comes into the world. When everyone knows the good and then the not good comes into being" (Henricks, 1989, p. 54). Daoist compassion is expressed in the Sage's approach to the constant opposites that life presents:

The ten thousand things arise, but he (the Sage) doesn't begin them;

He acts on their behalf, but doesn't make them dependent;

He accomplishes his tasks, but he doesn't dwell on them (Henricks, 1989, p. 54)

This passage presents an image of a kind of non-egoic impartial compassion and the scope of support or compassion for all phenomenon that arise: good and not good, beautiful and ugly etc.

Chapter 29 expands on the concept of frugality or moderation. It says:

The world is a sacred vessel; 
It is not something that can be acted upon.

Those who act on it destroy it;

Those who hold on to it lose it.

…

Therefore the Sage:

Rejects the extreme, the excessive, and the extravagant (Henricks, 1989, p.81).

The Daodejing does not just assert that one should be compassionate, frugal and humble; it provides reasons. I believe it is common in western thinking to view the world as a place that is simply substance or matter, but here the Daodejing holds that the world is sacred. The consequence of the imposition of human will upon the world is destructive to the sacred, resulting in the loss of the sacred. Therefore frugality and moderation preserve the sacred in the world and are a treasure along with compassion and humility.

It seems logical that if the world is sacred then we should be walking upon the earth and amongst our fellow earthly travellers with humility. The Daodejing speaks to and provides reasons for humility. Chapter 7 states that Heaven and Earth last a long time because they don't live for themselves (Henricks, 1989). Therefore the Sage:

Puts himself in the background yet finds himself in the foreground;

Puts self-concern out of his mind, yet finds that his self-concern is preserved (Hendricks, 1989, p. 59)

This statement expresses an underlying theme of the Daodejing and that is if the Sage aligns him or herself with nature (the dao) then personal transformation will come about and benefits will acrue. There is a subtly underlying this in that if the individual aligns themselves with the intention of gaining benefits then this is not virtue and the outcomes sought do not arise. In this passage, the alignment involves selflessness and humility because the earth and nature give selflessly to all: high and low, therefore those cultivating the dao should follow suit.

In Chapter 8 the Sage is advised to be like water which is often a metaphor for the dao. Thus the Sage does not compete, and seeks out the low position; the position that people abhor and detest. In so doing the Sage is without fault (Henricks, 1989). Finally Chapter 10 appears to articulate an aspect of virtue that is similar to that expressed by Armstrong and encompasses compassion and humility. In what appears to be advice to a Sage who is a leader it states:

Give birth to them and nourish them.

Give birth to them but don't try to own them;

Help them to grow but don't rule them.

This is called Profound Virtue (Henricks, 1989, p. 62)

Here again this chapter continues with the theme of alignment with nature as a means of personal cultivation and specifies the kind of behaviour a Sage must undertake. Nature gives birth and nourishes and yet does not claim ownership or attempt to impose will upon life and the Sage must follow in order to successfully cultivate. These are the acts of a generous, compassionate and humble person which contribute to the Sage's development as well as those around him or her.

It should be noted that the humbleness articulated here extends to eschewing: self-interest, fame, wealth, and power but does not include self-abnegation. Henricks (1989) interprets Chapter 13 of the Daodejing to suggest: "the person who should be entrusted with ruling the world is precisely the one who cares more for his own life than he does for wealth, honor, and power" (p. 212). This interpretation is consistent with the Neiye which holds that through cultivating virtue one returns to one's unique innate dao given nature and therefore, achieves union with the dao (Culham, 2013).

\section{Daoist Pedagogy of Compassion}


Given this other worldly view on compassion, one might ask: how is it cultivated? While the Daodejing does not provide cultivation instructions, it points to the Neiye (Roth, 1999) as the method in Chapter 16 where it advises the reader to "Take emptiness to the limit" and "Maintain tranquility in the center" (Henricks, 1989, p. 68). According to the Neiye, tranquility is the guiding principle of humans and therefore, it gives great attention to cultivation of physical, emotional, mental and spiritual tranquility (Roth, 1999). The underlying assumption in the Neiye and the Daodejing is that if the Sage aligns him or herself with the dao (nature) then virtue will spontaneously emerge in their lives. That is they are permiting the dao that is within to express itself. The first two chapters of the Neiye state that the outcome of this practice is the emergence of virtue (Culham, 2013) and I have noted above that compassion, frugality and humility are aspects of virtue. The Neiye proposes that virtue emerges unselfconsciously as a result of contemplation and it is not primarily the consequence of conscious practice (Culham, 2013; Roth, 1999). This concept is founded on the physicality of life and being. Roth (1991) held "One of the most ancient assumptions about human psychology in China is that the various aspects of human psychological experience are associated with, or even based on, certain physiological substrates or conditions" (p. 602). The practices advocated in the Neiye, which link "psychological experience to physiological conditions" (Roth, 1991, p. 603), are fundamental to Daoist teachings. While Daoism has been seen as esoteric and mystical, it is rooted first and foremost in physical being. Lai (2003) notes that "Daoism situates the power of the dao in the reality closest to us, most importantly in our own physical bodies" (p. 280). Emphasizing the importance of life, Lai (2003) quotes a fifth century Daoist text, which stated: "A dead prince is not worth a live rat" (p. 280). Therefore Daoist pedagogy depends on, begins with and is rooted in the physical body (Culham, 2013).

The idea that virtue and in particular compassion emerges unconsciously out of a meditative practice rooted in the body is not an insignificant point. It marks a clear departure from Confucians who held that consciously practicing the rites and virtues such as compassion were important to the development of virtues (Csikszentmihalyi, 2006). Most of us would, I believe, agree with the Confucians on this point based on our emphasis and experience with conscious cognitive learning and education in our modern society. That is, our experience and culture tells us that in order to learn and improve at something you have to study it and practice it. Daoists however criticised Confucians "who teach the techniques of Humaneness and Rightness yet cannot personally practice their own teachings" (Roth, 2010a, p. 81) and proposed that cultivating virtues required inner cultivation which works with unconscious mental processes and spontaneously results in the experssion of virtues. Indeed this is consistent with the view expressed in Chapter 38 of the Daodejing which holds that the highest virtue is that which is expressed spontaneously and unconsciously whereas virtue expressed consciously is not virtue (Culham, 2013).

What does this mean regarding cultivating compassion? Taken in the context of Daoist practice, inner spontaneous transformation is vital to outward behaviour and contemplative practices are central to the transformation. But the philosophical underpinning of Daoism provides some further insights. Often we assume that we must behave compassionately, implying an outward focus on the other. But in reading the following pairs I interpret the first of the pairs as an inward attitude, or state of mind and the second is an outward manifestation. So let me repeat them:

Now, it's because I'm compassionate that I therefore can be courageous;

And it's because I'm frugal that I therefore can be magnanimous;

And it's because I don't presume to be at the forefront in the world that I therefore can be the head of those with complete talent.

These lines can be considered in the context of Daoism as a description of an inner state of mind and outward behaviour as well as in the context of development from the level of novice to sage. I interpret the three lines above from the perspective of the inner state of mind: a novice begins by working towards achieving an attitude of compassion for self, begins to be frugal in habits and acknowledges his/her accomplishments with an attitude of humility. This inner state of mind enables one to be courageous in the face of life's challenges, magnanimous with others and to be a leader. Why from a Daoist perspective do I consider compassion for myself? 
In Daoist thinking, humans are a microcosm of the universe and therefore contain all of the possiblities of the universe: yin and yang, good and bad, ugly and beautiful. It is only through compassion for oneself and acknowledgement of all aspects of self, good and bad, with equanimity that one can learn to be compassionate with self. If one is able to recognize the polarities of self, one must be humble as one is aware of one's shortcomings. Also one must be frugal, as to take anything to excess will overemphasize one or the other of the opposites that we harbour within and put us out of balance. Therefore compassion begins with an acceptance of self as we are and in this acceptance we are transformed both inwardly and outwardly. This interpretation begins with two types of duality, yin and yang, inward and outwards. As the student accepts the duality of his or her inner world, the yin and yang of the self, an inner sense of unity, wholeness and nondual awareness emerges into consciousness. This achievement is a movement from novice to a higher level of cultivation. When this awareness appears, a sense of equanimity arises regarding the vagaries of the external world and one is perhaps more dispassionate and more able to nourish all life that emanates from the dao.

One of the goals of Daoist cultivation is to achieve awareness of one's innate self (Roth, 1999), and it seems to me that full awareness and acceptance of the totality of one's self (ugly, beautiful, loud, quite, sad, happy) is what is meant by this. This is a step on the way to the ultimate goal of Daoist cultivation and that is to merge with the dao through awareness of one's innate dao given nature (Roth, 1999). When this internal unity arises which might be thought of as an nondual awareness of self, then the next step is a perception of unity with the dao and this is a sagely accomplishement. The outcome is that one acts spontaneously and naturally according to the needs of the whole and this is percieved as compassionate and courageous by others. One can be magnaimous because one experiences the abundance of the universe and there is no need to hold onto anything, and one appears humble because there is no need for self agrandizment. The progression from novice to sage is not linear. It may be possible for the novice to behave sagely at certain times and under certain circumstances. The indication of a sage however, is one who integrates the internal and external and is consistently able to nourish life.

Summarizing the foregoing, according to the Daodejing, compassion is a human activity, positioned cosmologically in human affairs between Heaven and Earth. However it is informed or influenced by Heavenly principles. The Daoists hold that everything emanates from the dao including humans who, no matter their station in life or the misdeeds they may have committed, are worthy of compassion. The compassion called for by Daoists is impartial, expects nothing in return, and is not possessive. The Daodejing holds that compassion is first among the virtues of compassion, frugality and humility. Frugality is called for as part of the triad of virtues because the earth is sacred and the human propensity of acting on the world destroys it. It stands to reason that if the earth and all upon it are sacred then humans should tred the earth with humility. The form that this takes is specified. One must not lead but rather act with the intention of staying hidden or behind, and not pursue self interest. Paradoxically this triad of virtues results in beneficial outcomes. That is, those who are compassionate are courageous, the frugal are magnanoumous and the humble are leaders (Henricks, 1989). The consequences of not practicing these virtues is death. While these forms of compassion appear to be selfless and must be practiced one must still care for one's own life through cultivation of virtue. Finally the primary means by which virtues in general and specifically compassion are to be cultivated is through contemplative practices that emphasize tranquility. These practices align the person with the dao resulting in the spontaneous manifestation of virtue in their lives.

\section{Mandela, an Exemplar of Compassion}

Daoists hold that individuals of exempary virtue and compassion set an example that influence others to be virtuous. I felt to be consistent with this view, it would be helpful to provide an account of someone who embodied compassion. While I wrote this piece and contemplated what appeared to me as the impossibly high standard articulated by the Daoists for compassion, I wondered who might provide a good example of this virtue. It happened that on December $5^{\text {th }}$ 2013, Nelson Mandela passed away and the news was full of accounts of his great accomplishments and stories that illustrated his character. Daoism has its roots in the ancient culture of China that predates written language (Kirkland, 2004) and one might think that Mandela has nothing to do with Daoism. He likely knew very little of Daoism if anything at all. From a Daoist 
perspective however, this is not a concern as the foundation of Daoist philosophy and practice is the unbaiased acceptance and observation of nature. Thus, sagely behaviour certainly could arise from any human and not just those who are Chinese or who engage in Daoist practices.

Mandela was born into a traditional Thembu culture of east Africa and later was trained in the Christian tradition. His father was an advisor to the king of the Thembu people (Nelson Mandela Foundation, 2014). Mandela was therefore familiar with both the traditional culture of East Africa and Christianity. By his example of forgiveness and compassion, his influence extended far and wide geographically and across time. According to Daoists this is the sign of a highly cultivated sage (Major, et al., 2010).

After 27 years in jail, instead of resentment and retribution, Mandela was a serene man who sought reconciliation, forgiveness and equality for all (Arsenault \& Mansbridge, 2013). This wasn't just a political position. An anecdote recounted by George Bizos, his lawyer, who met him in prison shortly after his incarceration is a good illustration (Bizos \& Cooper, 2013). Upon entering the prison grounds Bizos encountered Mandela surrounded by a phalnax of white prison guards: 2 in front, 2 behind, and 2 on each side. After the pleasantries of greeting one another, Mandela proceeded to introduce Bizos to what he refered to as his honour guard, introducing each of them individually by name. The white guards were taken aback as it was not something they expected of a black man. Not only that, throughout his time in prison, Mandela who was a lawyer himself, gave legal advice to his captors. Mandela treated all people with the dignity that should be accorded to human beings (Bizos \& Cooper, 2013).

Michael Den Tandt (2013) said: "He had the very rare gift of compassion with strength - or strength, with compassion - that makes a truly great leader" (pp. B1, B4). I repeat one stanza of entry 67 on compassion in the Daodejing that appears to describe Mandela:

Now, it's because I'm compassionate that I therefore can be courageous;

And it's because I'm frugal that I therefore can be magnanimous;

And it's because I don't presume to be at the forefront in the world that I therefore can be the head of those with complete talent. (Henricks, 1989, p.38)

Mandela is an exemplar of kind of other worldly compassion the Daodejing articulates.

\section{Teaching and Learning Compassion}

Mandela is an exemplar of compassion that stands apart from our usual experience, but at the same time challenges us to aspire to a higher ideal. What about ordinary people? Where do they start and and how might teaching compassion work in an educational setting? For a number of years now I have witnessed students and others experience personal change that might be described as a move from a self-centered perspective to one that is empathetic and compassionate towards others.

Since 2010, I have taught ethics classes at the Sauder School of Business at UBC that incorporate, among other activities, development of emotional intelligence accompanied by brief meditative practices (Culham, 2013). In this section I draw on my experience with these classes to describe the development of compassion in students. I believe that compassion first requires a feeling of empathy for others, but paradoxically in these classes I begin with a focus on the self which provides a foundation for compassion. I start with a brief description of the activities in the class and then provide a typical scenario that captures the transformation from a narrow self-focus to a broader concern on the part of students.

A central goal of the class is to shift the orientation of student learning from the usual external focus of university education subjects such as finance, accouting and logistics to a focus that attends to students' internal world. This is usually a unique experience for students as few classes have this as their objective. Consistent with this orientation students engage in the following:

1. exercises to know their purpose or calling; 
2. meditative exercises that help them become aware of their emotions and where they physically feel them, and

3. structured interpersonal interaction challenging them to develop new social skills, such as informing others of your thoughts and feelings, listening to others and conflict management.

The first two exercises align with the concept advocated in the Neiye that knowing one's innate self is a path to cultivation of virtue (Culham, 2013). It is also consistent with the observation made by Roth (1991) regarding the views expressed in the Neiye that emotional psychological experiences are based in the body, an ancient insight observed in modern neuroscience (Damasio, 1994; Greene, 2009). The third exercise noted above is directed at social interaction, however, it also helps to increase the student's awareness of themselves as it is through difficult or challenging social interactions that internal emotions can run high. It is not hard to imagine that emotions can be intense during a conflict but this is not the only way that emotions can be intense.

Students are advised to select a social skill they feel they need to improve; for example, if a student habitually tells others their thoughts and feelings they are advised to practice listening. The behaviour practice I suggest to students might read something like: "five times a week I will actively listen to others without interruption until they have finished their statement and then I will repeat back to them what I thought I heard and ask if I have it right". These students often report that it takes great patience and intense self control to listen when all they want to do is offer their opinion. The urge to say something is so intense some speak of wanting to jump out of their skin. Students are encouraged to pay attention to and silently acknowledge to themselves in the moment how they feel in these situations. For example someone practicing listening might say silently, "I feel like saying something right now." In many cases acknowledging their intense feelings provides the student with relief from the impluse to act and may be the seed for transformation. This phenomenon is well documented in western psychotherapy and is known as affective release enabling the person to relate better to others (Fosha, 2000). The intention of these exercises is to develop emotional self-awareness, helping one to relate socially with others. That is, before one can develop awareness of emotions in others, a foundation of awareness of one's own emotions is necessary (Goleman, Boyatzis, \& McKee, 2002).

How does compassion emerges out of this? In their initial reports, some students stated that they find others they disagree with, or who don't share their interets, difficult to be with or difficult to listen to and in some cases they are derisive of others who hold differing views. In their final reports they often report an increased awareness of emotions in themselves and others and a more accepting and empathetic attitude to others who are different. They articulate more patience and willingness to consider other's views. In turn they notice that others are more willing to engage with them socially. This is not the same as forgiving others who have harmed one but it demonstrates a significant move from a self-centered perspective to one that reaches out to others.

I believe the foregoing is consistent with the idea of integrating the yin and yang of self. Taking the skill of learning to listen when one is used to speaking as an example. This exercise brings into the student's awareness an imbalance in their habits, the value of engaging in the opposite of their usual habit and acknowledgement of the emotions associated with resisting the temptation to speak. As I mentioned earlier these emotions often can be intense, which when recognized and acknowledged by the student relieve the impulse to act. This is an integrating process resulting in an acceptance of unacknowledged aspects of self allowing the person to choose how to act rather than impulsively act. It appears that the experience of accepting and integrating unacknowledge aspects of the student's self enables the student to be more accepting and compassionate with others.

Karen Armstong (2012) identified eight elements involved in the process of developing compassion and I mention four that appear to describe what is going on in my classes. They are: starting small, selfcompassion, person to person connections and relationship. In my classes students are engaged in practicing simple social skills such as listening, and informing; activities that attend to working with others in relationship. In addition, students are asked to engage in self-awareness exercises through meditation that I believe helps with self-compassion. Often students mention that they weren't aware of how much their lives were filled with emotion, indicating an increase in self-awareness, self-acceptance and compassion. This 
element is related to Daoism in that Daoists claim the key to developing virtue is to return to one's innate given self through meditative practices (Culham, 2013). I can't say which of the elements contribute to student transformation, but I do know that students value improving their self-awareness and they do report a transformation in outlook and relationship with others. I believe it is possible to teach compassion utilizing a combination of eastern and western pedagogical instruments. The work I report here is in its initial phases and deserves to be further evaluated and developed.

This paper began with Karen Armstrong's definition of compassion, explored the Daoist concept of compassion as articulated in the Daodejing, considered the exemplar of compassion in the person of Nelson Mandela relating it to the Daoist description of compassion, and landed on practical means of developing compassion in a classroom setting that integrates western and eastern practices. There is no doubt our world and the people in it need more compassion for ourselves, one another and the planet. It is my hope that this path is exlpored and engaged in more fully by all and particularly our current and future leaders. All one has to do is turn to the example of Mandela to see how one person's compassion and resolve can achieve the impossible transforming division, anamosity and hatred to unity, civility and acceptance.

\section{References}

Armstrong, K. (2012, March), Compassion. Elements of Compassion. Seminar conducted at Simon Fraser University, Vancouver. B.C.

Aresenault A. (Reporter), Mansbridge P., (Anchor). (2013, December 5). The National. Toronto, ON: CBC

Charter for Compassion, (2013, November 23). An Initiative to Promote Compassion Around the World. Retrieved from http://charterforcompassion.org/charter

Bizos, G. (Interviewee) \& Cooper, A., (Anchor). (2013). Bizos recalls Mandela's life in prison. In, Anderson Cooper 360. Atlanta Georgia: Turner Broadcasting System Inc.

Csikszentmihalyi, M. (2006). Material virtue: Ethics and the body in early China. Boston: Brill.

Culham, T. (2013). Ethics education of business leaders: Emotional intelligence, virtues and contemplative learning. In J. Lin, R. Oxford, (Eds.). Book Series: Transforming Education for the Future. Charlotte: Information Age Publishing.

Damasio, A. R. (1994). Descartes error. New York: Putnam.

Den Tandt, M. (2013, Dec 5) Nelson Mandela: A great man, great spirit, great soul. The Vancouver Sun , pp B1, B4.

Fosha, D. (2000). The transforming power of affect: A model for accelerated change. Basic Books.

Goleman, D. Boyatzis, R. E., \& McKee, A. (2002). Primal leadership: Realizing the power of emotional intelligence. Boston: Harvard Business School Press.

Greene, J.D. (2009). The cognitive neuroscience of moral judgment. In M. S. Gazzaniga (Ed.), The cognitive neurosciences (4th ed.) (pp. 987-1002). Cambridge, MA: The MIT Press.

Henricks, R. G. (1989). Lao-tzu: Te-tao ching: A new translation based on the recently discovered ma-wang-tui texts. New York: Ballantine Books.

Lai, C. T. (2003). Commentary: A Daoist perspective. Journal of Advanced Nursing, 46(3), 279.

Major, J. S. Queen, S. A., Meyer, A. S., \& Roth, H. D. (2010). Introduction. In J. S. Major, S. A. Queen, A. S. Meyer, \& H. D. Roth (Eds.), The Huainanzi: A guide to the theory and practice of government in early Han China (pp. 1-40). New York: Columbia University Press.

Meyer, A. S. (2010). Appendix A: Key Chinese terms and their translations. In J. S. Major, S. A. Nelson

Nelson Mandela Foundation (2014). Biography. Retrieved from: http://www.nelsonmandela.org/content/page/biography

Queen, A. S. Meyer, \& H. D. Roth (Eds.). The Huainanzi: A guide to the theory and practice of government in early Han China. New York: Columbia University Press.

Roth, H. D. (1991). Psychology and self-cultivation in early taoistic thought. Harvard Journal of Asiatic Studies, 51(2), 599-650.

Roth, H. D. (1999). Original Tao: Inward training (nei-yeh) and the foundations of Taoist mysticism. New York: Columbia University Press. 
Roth, H.D. (2010a). Activating the genuine. In J. S. Major, S. A. Queen, A. S. Meyer, \& H. D. Roth (Eds.), The Huainanzi: A guide to the theory and practice of government in early Han China (pp. 84-108). New York: Columbia University Press.

Roth, H. D. (2010b). Quintessential spirit. In J. S. Major, S. A. Queen, A. S. Meyer, \& H. D. Roth (Eds.), The Huainanzi: A guide to the theory and practice of government in early Han China (pp. 240-260). New York: Columbia University Press.

\begin{abstract}
About the Author
Tom Culham, an engineer with a 30-year business career, recently completed a Ph. D (2012) in the Faculty of Education at Simon Fraser University. His thesis, now published as a book: Ethics Education of Business Leaders drew on: neuroscience, psychology, virtue ethics, Daoist contemplative practices, and leadership education emphasizing emotional intelligence. His additional research interests include: embodied learning, and evaluating the ethics pedagogy described in his thesis. In June of 2013, he was recognized for academic excellence by Simon Fraser University's Faculty of Education with the Dean of Graduate Studies Convocation Medal. He is currently principal of his consulting firm, a sessional instructor of supply chain and ethics courses at the Sauder School of Business, and a research associate at the Center for Applied Ethics, University of British Columbia Vancouver.
\end{abstract}

Email: tom.culham@sauder.ubc.ca

Web pages: http://ethics.ubc.ca/

http://www.sauder.ubc.ca/Faculty/People/Faculty_Members/Culham_Thomas 